\title{
Comparison between two Fluid Management Techniques of Ringer lactate and Hydroxyethyl Starches in cases of Burn
}

\author{
Kashif Ali, ${ }^{1}$ Hassan Mahmood Tabassum, ${ }^{2}$ Mohtamam Nazir, ${ }^{2}$ Sultan Ahmed Owaisi, ${ }^{2}$ Sajid Anwar, ${ }^{2}$ Muhammad \\ Nauman Ashraf ${ }^{2}$
}

\begin{abstract}
Background: Fluid replacement is one of the important issues in the management of burn cases.

Objective: To compare the outcome between Ringer lactate and Hydroxyethyl starches (HESs) in cases with burn injuries.

Methodology: Study design: Randomized controlled trial. Place and duration of study: Department of Plastic Surgery, Sheikh Zayed Hospital, Rahim Yar Khan, from June to December 2018. Study subjects selected were those who had a burn of any type (thermal, chemical, electric) and at least more than $10 \%$ of the surface area of the body. The cases were then divided into two equal groups. The fluid requirement was calculated according to the Parkland formula. After this, the cases in group A were given Ringers lactate solution $500 \mathrm{ml}$ while those in group B were given $500 \mathrm{ml}$ of $6 \%$ hydroxyethyl starches (HESs) and further fluid was administered in group A as ringer only and in group $\mathrm{B}$ as ringer and HES in a ration of 2:1. The cases were then followed to look for various outcomes in the form of urine output, serum creatinine, and mean hospital stay.

Results: In this study, there were a total of 60 cases (30 in each group). The mean age in group A and B was 17.33 \pm 5.39 vs $19.11 \pm 4.79$ years $(p=0.33)$. Mean hospital stay was $14.65 \pm 3.31$ vs $13.49 \pm 2.78$ days with $p=0.41$. Mean urine output per day was $1645.81 \pm 143.47 \mathrm{vs} 1705.31 \pm 165.83 \mathrm{ml}$ with $\mathrm{p}=0.43$ and mean creatinine in group $\mathrm{A}$ and $\mathrm{B}$ was $1.79 \pm 0.38$ vs $1.83 \pm 0.44$ with $\mathrm{p}=0.86$.
\end{abstract}

Conclusion: There was no significant difference in both the groups regarding urine output, creatinine, and mean hospital stay.

Keywords: Creatinine, Ringer lactate, HES

Article Citation: Ali K, Tabassum HM, Nazir M, Owaisi SA, Anwar S, Ashraf MN. Comparison between two Fluid Management Techniques of Ringer lactate and Hydroxyethyl Starches in cases of Burn. JSZMC 2020;11(3):13-16. DOI: https://doi.org/10.47883/jszmc.v11i03.5

\section{Introduction}

Worldwide, the incidence is on the rise regarding burn cases and specialized centres are being designed at the endpoints to provide better and safer management via specialized and structured programs to such cases to avoid the high degree of morbidity and mortality associated with such cases. ${ }^{1}$ The numbers are still higher in underdeveloped and developing countries and might be due to a lack of resources. ${ }^{1,2}$ Burn injuries can be due to thermal, electrical, chemical, and various other subtypes and can lead to a wide variety of physiological and pathological changes in the body and especially where it involves the greater surface area. There are a number of scoring methods and the rules of nine is most widely practiced to grade the severity of the injury. ${ }^{3,4}$
Skin is the best dressing and its loss in cases of burns can lead to not only an increased risk of infections but also ends up in diverse hemodynamic changes and it's a nidus for a great amount of fluid, electrolyte, and protein losses. This all in conjunction leads to diverse hemodynamic and acid-base disturbances in the body which can impair the normal functionality of the body and pose certain problems. ${ }^{5,6}$

Fluid replacement is one of the great challenges in the burn cases and there is always an ongoing debate regarding the choice and rate of fluid administration as increased permeability leads to increased losses and excess free fluid can also cause tissue edema. Parkland's formula is the most commonly used for fluid resuscitation and choice of fluid is always controversial and saline and ringer lactate both are used and practiced globally. ${ }^{7,8}$ In burns patients

1. Department of Plastic Surgery, Sheikh Zayed Medical College/Hospital, Rahim Yar Khan, Pakistan.

2. Department of General Surgery, Sheikh Zayed Medical College/Hospital, Rahim Yar Khan, Pakistan.

Correspondence: Dr. Kashif Ali, Associate Professor, Department of Plastic Surgery, Sheikh Zayed Medical College/Hospital, Rahim Yar Khan, Pakistan 
resuscitation or revival with isotonic crystalloid fluid, such as Lactated Ringer has been customarily utilized in patients to gauge the sum of substitution liquid required in the initial 24 hours of injury (the main portion of the liquid is given inside 8 hours), with the adequacy observed through crucial signs and urinary output. However, these endpoints ought to have been investigated in ongoing examinations on the grounds that noninvasive boundaries might be deficient for identifying malperfusion. Huge volumes of revival liquid have been related to an expanded danger of "fluid creep" resulting in infectious complications, Acute Respiratory Distress Syndrome (ARDS), and mortality., Hypertonic liquid revival gives off an impression of being an alluring decision since a mixture of hypertonic sodium increases plasma osmolality and limits cell edema development. Also, intravenous organization of colloid arrangement, which makes a higher osmotic weight applied by proteins, can pull in water from cells into the blood vessels. However, the utilization of colloid arrangements, for example, hydroxyethyl starch (HES) to revive patients with consumes stays disputable in light of the fact that it might improve the danger of over-burdening of colloids in interstitial compartments. Numerous investigations have assessed whether a hypertonic, a hyperoncotic, or an isotonic arrangement is a superior decision for liquid revival in patients with serious consumes. ${ }^{10-12}$ It is a fact that fluid loss is the major problem faced after major burn injuries, and effective fluid resuscitation is one of the focus of burn treatment of today. This study was planned to compare the outcome between Ringer lactate and Hydroxyethyl starches (HESs) in cases with burn injuries.

\section{Methodology}

This was a quasi-experimental study that was carried out at the Department of Plastic Surgery, Sheikh Zayed Hospital, Rahim Yar Khan from June to December 2018. In this study, the cases of either gender and age more than 5 years were included. Consecutive subjects were selected that had burn of any type (thermal, chemical, electric) and at least more than $10 \%$ of the surface area of the body presenting within 24 hours and having normal serum creatinine levels. The cases were then divided into two equal groups by random number allocation method. The cases in both the groups were managed according to standard protocols of the burns and prophylactic and therapeutic pain killers and antibiotics were administered and local creams were applied according to the standard guidelines. The fluid requirement was calculated according to the standard Parkland formula and 1 litre of ringer lactate was given to both the groups. After this, the cases in group A were given Ringers lactate solution $500 \mathrm{ml}$ while those in group B were given $500 \mathrm{ml}$ of $6 \%$ hydroxyethyl starches (HESs) and further fluid was administered in group A as ringer only and in group $\mathrm{B}$ as ringer and HES in a ration of $2: 1$. The cases were then followed to look for various outcomes in the form of urine output, serum creatinine and mean hospital stay. Ethical approval was sought from Institutional Review Board. The data were entered and analyzed by SPSS-version 23.0. Qualitative variables were compared by chisquare test and quantitative with the help of an independent sample t-test and post-stratification $\mathrm{p}$ value of less than 0.05 was taken as significant.

\section{Results}

In this study, there were a total of 60 cases ( 30 in each group). The mean age in group $\mathrm{A}$ and $\mathrm{B}$ was $17.33 \pm 5.39$ vs $19.11 \pm 4.79$ years $(p=0.33)$ and the mean duration of the burn was $3.87 \pm 0.73$ vs $3.51 \pm 0.67$ hours with $\mathrm{p}=0.67$ as in table I. There were $20(66.67 \%)$ vs $19(63.33 \%)$ males in groups A and $B$ with $p=0.33$ as in table II. Mean hospital stay was $14.65 \pm 3.31$ vs $13.49 \pm 2.78$ days with $p=0.41$. Mean urine output per day was $1645.81 \pm 143.47$ vs $1705.31 \pm 165.83$ with $p=0.43$ and mean serum creatinine in group A and B was $1.79 \pm 0.38$ vs $1.83 \pm 0.44$ with $\mathrm{p}=0.86$ as in table III.

Table-I: Quantitative study variables $(n=30$ in each group)

\begin{tabular}{|c|c|c|c|}
\hline \multirow{2}{*}{ Variables } & \multicolumn{2}{|c|}{ Group } & \multirow{2}{*}{ P value } \\
\cline { 2 - 3 } & A & B & \\
\cline { 2 - 3 } & $\begin{array}{c}\text { Mean } \pm \\
\text { SD }\end{array}$ & Mean \pm SD & \\
\hline Age (years) & $17.33 \pm 5.39$ & $19.11 \pm 4.79$ & 0.33 \\
\hline Weight (kg) & $32.14 \pm 5.43$ & $35.13 \pm 8.03$ & 0.45 \\
\hline $\begin{array}{c}\text { Duration of burn } \\
\text { (hrs) }\end{array}$ & $3.87 \pm 0.73$ & $3.51 \pm 0.67$ & 0.67 \\
\hline
\end{tabular}


Table - II: Qualitative study variables $(n=30$ in each group)

\begin{tabular}{|l|c|c|c|}
\hline \multirow{2}{*}{ Variables } & \multicolumn{2}{|c|}{ Group } & \multirow{2}{*}{ P value } \\
\cline { 2 - 3 } Sex & A & B & \multirow{2}{*}{0.33} \\
\hline Male & $\begin{array}{c}20 \\
(66.67 \%)\end{array}$ & $19(63.33 \%)$ & \\
\hline Female & $\begin{array}{c}10 \\
(33.33 \%)\end{array}$ & $11(36.67 \%)$ & \\
\hline Burns Category & $\begin{array}{c}14 \\
\begin{array}{l}10 \% \text { TBSA } \\
\text { burn }\end{array}\end{array}$ & $13(43.33 \%)$ & \multirow{2}{*}{0.67} \\
\hline $\begin{array}{l}30-60 \% \text { TBSA } \\
\text { burn }\end{array}$ & $12(46.67 \%)$ & $14(46.67 \%)$ & \\
\hline $\begin{array}{l}>60 \% \text { TBSA } \\
\text { burn }\end{array}$ & $4(13.33 \%)$ & $3(10 \%)$ & \\
\hline
\end{tabular}

Table-III: Comparison of outcome in both groups

\begin{tabular}{|l|c|c|c|}
\hline \multirow{2}{*}{ Variables } & A & B & \multirow{2}{*}{$\begin{array}{l}\text { P } \\
\text { value }\end{array}$} \\
\cline { 2 - 4 } & Mean \pm SD & Mean \pm SD & \\
\cline { 2 - 4 } $\begin{array}{l}\text { Hospital stay } \\
\text { (days) }\end{array}$ & $14.65 \pm 3.31$ & $13.49 \pm 2.78$ & 0.41 \\
\hline $\begin{array}{l}\text { Mean urine } \\
\text { output (ml) }\end{array}$ & $1645.81 \pm 143.47$ & $1705.31 \pm 165.83$ & 0.43 \\
\hline $\begin{array}{l}\text { Mean serum } \\
\text { creatinine } \\
\text { (mg/dI) }\end{array}$ & $1.79 \pm 0.38$ & $1.83 \pm 0.44$ & 0.86 \\
\hline
\end{tabular}

\section{Discussion}

Fluid replacement is one of the cardinal points in the management of burn cases as an immense change is noted in the fluid, electrolyte, protein and acid-base status of the body. Increased permeability leak and losses are the mainstay of the underlying pathology. Crystalloids are considered as the treatment of choice for fluid replacement therapy but data has shown the role of colloid as well as have larger molecule and are unable to leak through the highly permeable membrane. ${ }^{9,10}$

In the present study, the mean hospital stay was $14.65 \pm 3.31$ vs $13.49 \pm 2.78$ days with $\mathrm{p}=0.41$. Mean urine output per day was $1645.81 \pm 143.47$ vs $1705.31 \pm 165.83$ with $\mathrm{p}=0.43$ and mean creatinine in group A (managed with ringer lactate) and $\mathrm{B}$ (managed with hydroxyethyl starches) was $1.79 \pm 0.38$ vs $1.83 \pm 0.44$ with $\mathrm{p}=$ 0.86 . These results were comparable to the studies done in the past which did not find any significant difference in both the groups and also found no bad outcome in cases that were managed with HES. ${ }^{11,12}$ According to a study done by Bechir $\mathrm{M}$ et al, they used similar protocols and compared these two modalities and included the cases that had burn area more than $15 \%$. They also did not find any significant difference in terms of mean urine output with $p=$ 0.90 , mean serum creatinine of both groups with $p=$ 0.97 . However, length of hospital stay was longer than the present study and was seen as 31 vs 29 days in ringer vs HES group with $\mathrm{p}=0.57 .^{12}$

The other studies have also supported the role of HES regarding the better outcome in fluid resuscitation. They further described that the risk of developing complications like fluid overload and ARDS was lesser in cases managed with HES as compared to aggressive fluid therapies compared. The studies not only used $6 \%$ but also $10 \%$ HES for fluid replacement and resuscitation but the risk of renal failure and long term renal replacement therapies was higher in such cases. ${ }^{12-15}$ The other studies favored the use of HES 130 and revealed that this has a benefit over other therapies in terms of a mortality benefit. ${ }^{15,16}$ According to a meta-analysis done by Kao et al, where they included 502 participants of burns and in this analysis they divided into two groups where they compared the iso-osmotic fluid resuscitation group, with the hyper-osmotic group and in the end they observed a significant decrease in the fluid load (vol/\% total body surface area [TBSA ]/weight) at 24 hours post-injury, with a mean difference of $-0.54(95 \%$ confidence interval $=$ -0.92 to -0.17$)$. No differences were observed in the urine output, creatinine level, and mortality at 24 hours post-injury between groups. ${ }^{16}$

According to another study done by Habib et al, they found that resuscitation with ringer lactate only according to standard Parkland formula was insufficient and there was further need for the additional sodium as well as colloids for end-organ perfusion. ${ }^{17}$ In another study done by $\mathrm{Hu}$ et al, they divided the cases of burn in seven groups and managed them with various modalities and it was seen that the group managed with pyurate and HESC combination was the best than the other groups like Saline. It was further described that the saline group was superior in renal preservation with $P=<0.05)$. ${ }^{18}$ Similarly Guilbert $P$ et al assessed various fluids and didn't find any significant difference in terms of one particular one. One had the edge in one aspect and the 
other in other terms especially saline had a better outcome in terms of renal injury prevention. ${ }^{19}$

However, the data analyzed among 25 trials, revealed that HES used in different strengths in various studies has increased the risk of death compared with crystalloid (risk ratio $1.10,95 \%$ CI 1.02 to 1.19$){ }^{20}$

Many studies have shown the evidence that burns patients who receive more quantity for resuscitation fluid is at more risk for complications and death. So the chosen types and amount of the fluid administered in major burns patients are generating controversy. Basically, such debates are aiming to look for an approach that is evidence-based for adequate fluid resuscitation.

\section{Conclusion}

This study concluded that there was no significant difference with fluid replacement with Ringer lactate and Hydroxyethyl starches (HESs) in cases with burn injuries, in terms of outcome regarding urine output, creatinine, and mean hospital stay.

\section{Author Contribution}

KA: Conception of work, design of work and revising. HMT: Design of work, Acquisition and analysis of data and drafting. MN \& SA: Interpretation of data and revising. SAO \& MNA: Interpretation of data, revising.

All authors critically revised and approve its final version.

\section{Conflict of interest: None \\ Resources of funding: Self}

\section{References}

1. Regar A, Hotwagner DT. Burn fluid management. Stat Pearls. 2019;4:1-3.

2. Bacomo FK, Chung KK. A primer on burn resuscitation. J Emerg Trauma Shock. 2011 Jan;4(1):109-13.

3. Romanowski KS, Palmieri TL. Pediatric burn resuscitation: past, present, and future. Burns Trauma. 2017;5:26.

4. Myburgh J. Patient-Centered Outcomes and Resuscitation Fluids. N. Engl. J. Med. 2018 Mar 01;378(9):862-863.

5. Coca SG, Bauling $\mathrm{P}$, Schifftner T, Howard CS, Teitelbaum I, Parikh CR. Contribution of acute kidney injury toward morbidity and mortality in burns: a contemporary analysis. Am. J. Kidney Dis. 2007 Apr;49(4):517-23.
6. Evers LH, Bhavsar D, Mailänder P. The biology of burn injury. Exp. Dermatol. 2010 Sep;19(9):777-83.

7. Pham TN, Cancio LC, Gibran NS., American Burn Association. American Burn Association practice guidelines burn shock resuscitation. J Burn Care Res. 2008 Jan-Feb;29(1):257-66.

8. Atiyeh BS, Dibo SA, Ibrahim AE, Zgheib ER. Acute burn resuscitation and fluid creep: it is time for colloid rehabilitation. Ann Burns Fire Disasters. 2012 Jun 30;25(2):59-65.

9. White CE, Renz EM. Advances in surgical care: management of severe burn injury. Crit. Care Med. 2008 Jul;36(7 Suppl):S318-24.

10. Reddy S, Weinberg L, Young P. Crystalloid fluid therapy. Crit Care 2016;20: 59.

11. Culleiton AL, Simko LM. Caring for patients with burn injuries. Nursing 2013; 43: 26-34.

12. Béchir M, Puhan MA, Fasshauer M, Schuepbach RA, Stocker R, Neff TA. Early fluid resuscitation with hydroxyethyl starch 130/0.4 (6\%) in severe burn injury: a randomized, controlled, double-blind clinical trial. Crit Care 2013; 17: R299.

13. Belba MK, Petrela EY, Belba GP. Comparison of hypertonic vs isotonic fluids during resuscitation of severely burned patients. Am J Emerg Med 2009; 27: 1091-6.

14. Bechir M, Puhan MA, Neff SB, Guggenheim M, Wedler V, Stover JF, Stocker R, Neff TA. Early fluid resuscitation with hyperoncotic hydroxyethyl starch 200/0.5 (10\%) in severe burn injury. Crit Care. 2010;17:R123.

15. Dubin A, Pozo MO, Casabella CA, Murias G, Palizas F $\mathrm{Jr}$, Moseinco MC, Kanoore Edul VS, Palizas F, Estenssoro E, Ince C. Comparison of 6\% hydroxyethyl starch 130/0.4 and saline solution for resuscitation of the microcirculation during the early goal-directed therapy of septic patients. J Crit Care. 2010;17:659. e651-658.

16. Kao Y, Loh EW, Hsu CC, et al. Fluid Resuscitation in Patients With Severe Burns: A Meta-analysis of Randomized Controlled Trials. Acad Emerg Med 2018; 25:320.

17. Habib M, Saadah L, Al-Samerrae M, Shoeib F, Mamoun M, Latif, G, et al. Does Ringer Lactate Used in Parkland Formula for Burn Resuscitation Adequately Restore Body Electrolytes and Proteins?. Modern Plastic Surgery, 2017;7:1-12.

18. Hu S, Dai Y, Gao M, Wang X, Wang H. Kidneys in rats subjected to burns. J Surg Res. 2018;1:003.

19. Guilbert P, Uusa G, Martin N, Abarca L, Barret JP. Fluid resuscitation management in patients with burns: update. Br J Anaesth. 2016;117(3):284-96.

20. Perel P, Roberts I, Ker K. Colloids versus crystalloids for fluid resuscitation in critically ill patients. Cochrane Database Syst Rev 2013;:CD000567. 